\title{
Perianal squamous cell carcinoma in a Quarter Horse colt
}

\author{
Carcinoma de células escamosas perianal em potro Quarto de Millha \\ Carcinoma epidermoide perianal en un potro Cuarto de Milla
}

Received: 01/13/2022 | Reviewed: 01/17/2022 | Accept: 01/25/2022 | Published: 01/26/2022

Ubiratan Pereira de Melo

ORCID: https://orcid.org/0000-0002-1253-2720

Centro Universitário Maurício de Nassau, Brazil E-mail: ubiratan_melo@yahoo.com.br

Cintia Ferreira

ORCID: https://orcid.org/ 0000-0003-2473-1580

Centro Universitário Maurício de Nassau, Brazil

E-mail: cinferre_vet@yahoo.com.br

\begin{abstract}
Squamous cell carcinoma (SCC) is a squamous epithelial neoplasm. They are solitary tumors with indolent expansion, are locally invasive, and can be seen in any part of the body. The most commonly affected sites are the head, orbital region, and genitalia of horses. Solar irradiation is one of the main causes, especially in depigmented and hairless areas. SCC is the neoplasm most frequently described in equine species. Several treatments have been described in horses, usually associated with surgical excision with different adjuvant therapies, hoping for a better prognosis and a decrease in cancer-related morbidity. Since the recurrence rates are high, especially in regions that do not have an adequate safety margin after tumor removal, multimodality treatment is essential. The aim of this report was to describe a case of perianal SCC in a Quarter Horse colt clinically treated with the immunomodulatory drug imiquimod. A three-year-old, grey-haired, male Quarter Horse was examined for diagnosis and treatment of an ulcerative lesion in the perianal region. According to the owner's report, the lesion appeared approximately 16 months ago. Based on the medical history and clinical examination, SCC was suspected. To confirm the clinical diagnosis, a biopsy was performed. Histological examination showed infiltrative neoplastic proliferation from the epidermis, consisting of malignant keratinocytes associated with hyperkeratosis, neutrophilic infiltrate, and foci of ulceration. The underlying dermis exhibited an intense chronic inflammatory infiltrate. The findings were compatible with SCC. Due to the location and extension of the lesion, we decided to use immunomodulatory therapy with imiquimod. After 16 weeks of imiquimod application, the lesion completely regressed. The horse was clinically followed for two years, and no recurrence was identified.
\end{abstract}

Keywords: Equine; Imiquimod; Immunotherapy; Keratinocytes; Neoplasm.

\section{Resumo}

O carcinoma de células escamosas (CCE) é uma neoplasia epitelial escamosa. São tumores solitários com expansão indolente, localmente invasivos e podem ser vistos em qualquer parte do corpo. Os locais mais comumente afetados são a cabeça, a região orbital e a genitália dos cavalos. A irradiação solar é uma das principais causas, principalmente em áreas despigmentadas e sem pelos. O CCE é a neoplasia mais frequentemente descrita na espécie equina. Vários tratamentos têm sido descritos em equinos, geralmente associados à excisão cirúrgica com diferentes terapias adjuvantes, na esperança de um melhor prognóstico e diminuição da morbidade relacionada ao câncer. Como as taxas de recorrência são altas, principalmente em regiões que não possuem margem de segurança adequada para remoção do tumor, o tratamento multimodal é essencial. O objetivo deste relato foi descrever um caso de CCE perianal em potro da raça Quarto de Milha tratado clinicamente com a droga imunomoduladora imiquimod. Um Potro da raça Quarto de Milha, macho, 3 anos de idade, tordilho, foi examinado para diagnóstico e tratamento de lesão ulcerativa na região perianal. De acordo com relato do proprietário, a lesão havia surgido há aproximadamente 16 meses. Com base no histórico e exame clínico, suspeitou-se de CCE. Para confirmar o diagnóstico clínico, foi realizada biópsia. O exame histológico mostrou proliferação neoplásica infiltrativa da epiderme, composta por queratinócitos malignos associados a hiperqueratose, infiltrado neutrofílico e focos de ulceração. A derme subjacente exibia um intenso infiltrado inflamatório crônico. Os achados foram compatíveis com CCE. Devido à localização e extensão da lesão, optou-se pela terapia imunomoduladora com imiquimode. Após 16 semanas de aplicação de imiquimod, a lesão regrediu completamente. O potro foi acompanhado clinicamente por dois anos, e nenhuma recorrência foi identificada.

Palavras-chave: Equino; Imiquimode; Imunoterapia; Neoplasia; Queratinócitos. 


\section{Resumen}

El carcinoma de células escamosas (CCE) es una neoplasia epitelial escamosa. Son tumores solitarios con expansión indolente, son localmente invasivos y pueden verse en cualquier parte del cuerpo. Los sitios más comúnmente afectados son la cabeza, la región orbital y los genitales de los caballos. La irradiación solar es una de las principales causas, sobre todo en zonas despigmentadas y sin pelo. El SCC es la neoplasia descrita con mayor frecuencia en la especie equina. Se han descrito varios tratamientos en caballos, generalmente asociados a la escisión quirúrgica con diferentes terapias adyuvantes, con la esperanza de un mejor pronóstico y una disminución de la morbilidad relacionada con el cáncer. Dado que las tasas de recurrencia son altas, especialmente en regiones que no tienen un margen de seguridad adecuado después de la extirpación del tumor, el tratamiento multimodal es fundamental. El objetivo de este reporte fue describir un caso de SCC perianal en un potro Quarter Horse tratado clínicamente con el fármaco inmunomodulador imiquimod. Un Quarter Horse macho de tres años de edad, rucio, fue examinado para el diagnóstico y tratamiento de una lesión ulcerosa en la región perianal. Según informe del propietario, la lesión apareció hace aproximadamente 16 meses. Con base en la historia clínica y el examen clínico, se sospechó SCC. Para confirmar el diagnóstico clínico, se realizó una biopsia. El examen histológico mostró proliferación neoplásica infiltrativa de la epidermis, que constaba de queratinocitos malignos asociados con hiperqueratosis, infiltrado neutrofílico y focos de ulceración. La dermis subyacente presentaba un intenso infiltrado inflamatorio crónico. Los hallazgos fueron compatibles con SCC. Debido a la localización y extensión de la lesión, decidimos utilizar terapia inmunomoduladora con imiquimod. Después de 16 semanas de aplicación de imiquimod, la lesión retrocedió por completo. El caballo fue seguido clínicamente durante dos años y no se identificó ninguna recurrencia.

Palabras clave: Equinos; Imiquimod; Inmunoterapia; Queratinocitos; Neoplasia.

\section{Introduction}

Squamous cell carcinoma (SCC) is among the most commonly reported malignant epithelial neoplasms in equids, accounting for $7-37 \%$ of all skin lesions. Although SCC may affect the skin and mucosa at any site, the usual sites for its development are non-pigmented skin and mucocutaneous junctions, such as the eyelids and external genitalia of horses (Armando et al., 2021; Porcellato et al., 2021). Several factors may contribute to its development, such as genetic susceptibility, age, and ultraviolet light exposure (Halleran et al., 2021). Papillomaviruses are the causative agents of certain types of SCC, but the biological mechanisms underlying tumor development and progression are still unclear (Hibi et al., 2019).

SCC is a malignant tumor of non-glandular epithelial tissue, composed of large epithelial cells, showing the presence of intercellular bridges and the production of keratin, occurring in the form of pearls or single keratinized cells. It is more common in older stallions and geldings on the penis and prepuce, but it has also been described in the nictitating membrane, tongue, nasal cavity, mouth, larynx, nasal sinuses, mediastinum, stomach, penis, vulva, and vagina (Hibi et al., 2019; MansoDíaz et al., 2019; Morrison et al., 2019; Stein et al., 2019; Raś et al., 2020).

SCC involving the eyelid, nictitating membrane, or conjunctiva are the most common carcinomas in horses [21]. In contrast to genital SCC, typically seen in older geldings, ocular SCC mainly occurs in younger horses of both sexes and 6-12 years of age [24].

SCC, in any species, often begins as small, nonhealing, slowly enlarging, granulating ulcers or as proliferative cauliflower-like masses resembling papillomas with a broader base. Granulating ulcerative lesions usually develop a crater-like appearance with indurated borders. The amount of fibrous tissue varies with individual lesions. Inflammation and secondary infections associated with lesions often complicate both recognition and diagnosis [14].

The aim of this report was to describe a case of perianal SCC in a Quarter Horse colt clinically treated with the immunomodulatory drug imiquimod.

\section{Case Report}

A three-year-old, grey-haired, male Quarter Horse was examined to diagnose and treat an ulcerative lesion in the perianal region. According to the owner's report, the lesion appeared approximately 16 months ago. At the time, he was 
examined by a veterinarian and no diagnosis was established. Several protocols based on healing ointments and antibiotic therapy were carried out during this period but without success.

On clinical examination, heart rate, respiratory rate, capillary filling time, gastrointestinal motility, and body temperature were within normal limits. Blood samples for hemogram and serum biochemistry were collected at the time of clinical examination, but no changes were observed. On clinical examination of the perianal region, a flat, ulcerated lesion covered with crusts surrounding the entire anal sphincter was observed (Fig. 1).

Figure 1 - Perianal squamous cell carcinoma in a Quarter Horse colt. In (A), ulcerative lesions can be seen in the perianal region (Arrows). In (B), the perianal region is observed after treatment with imiquimod demonstrating the absence of ulcerative lesions.

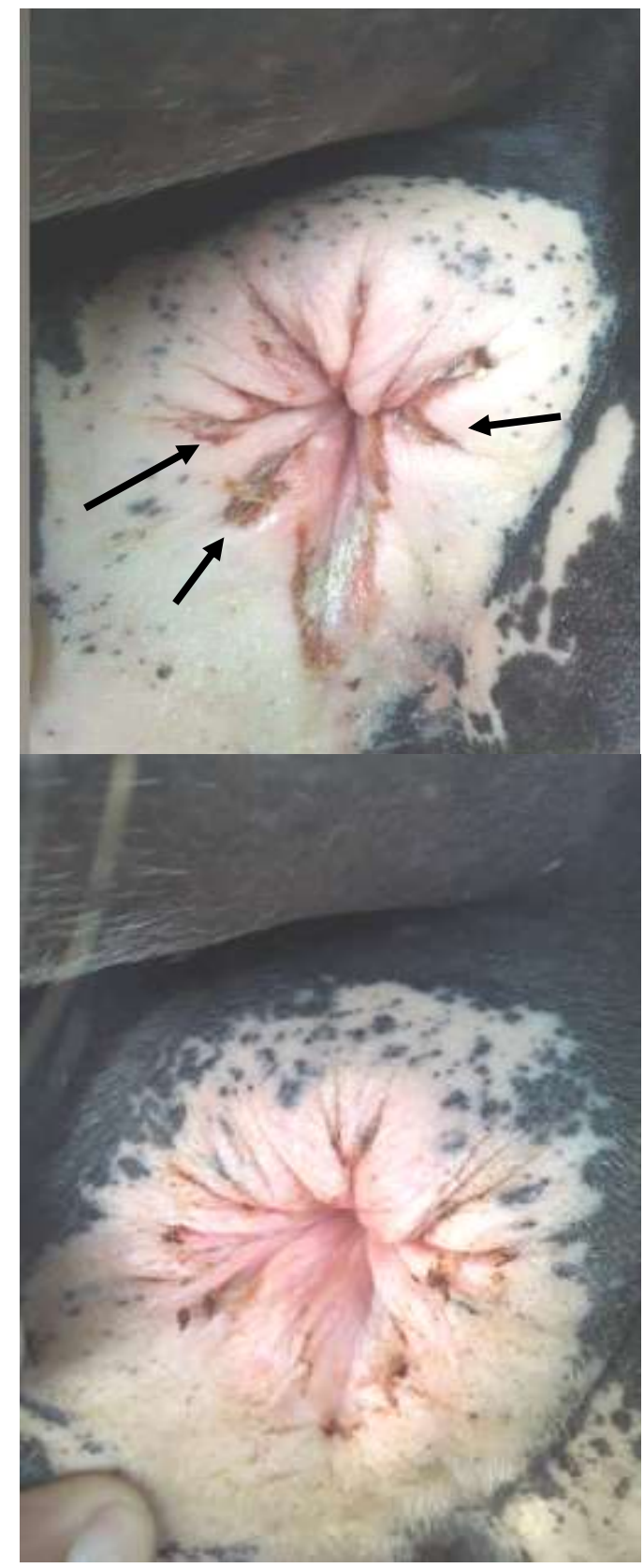

Source: Authors. 
Based on the medical history and clinical examination, SCC was suspected. To confirm the clinical diagnosis, a biopsy was performed. Histological examination showed infiltrative neoplastic proliferation from the epidermis, consisting of malignant keratinocytes associated with hyperkeratosis, neutrophilic infiltrate, and ulceration foci. The underlying dermis exhibited an intense chronic inflammatory infiltrate. The findings were compatible with well-differentiated SCC (Fig. 2).

Figure 2. Histopathological photomicrograph of equine perianal squamous cell carcinoma. On the periphery of the figure there are groups of cells with a tendency for keratinization. In the center there is an inflammatory infiltrate (Hematoxylin-eosin stain. A: $\times 10$ magnification; $B$ : $\times 40$ magnification).

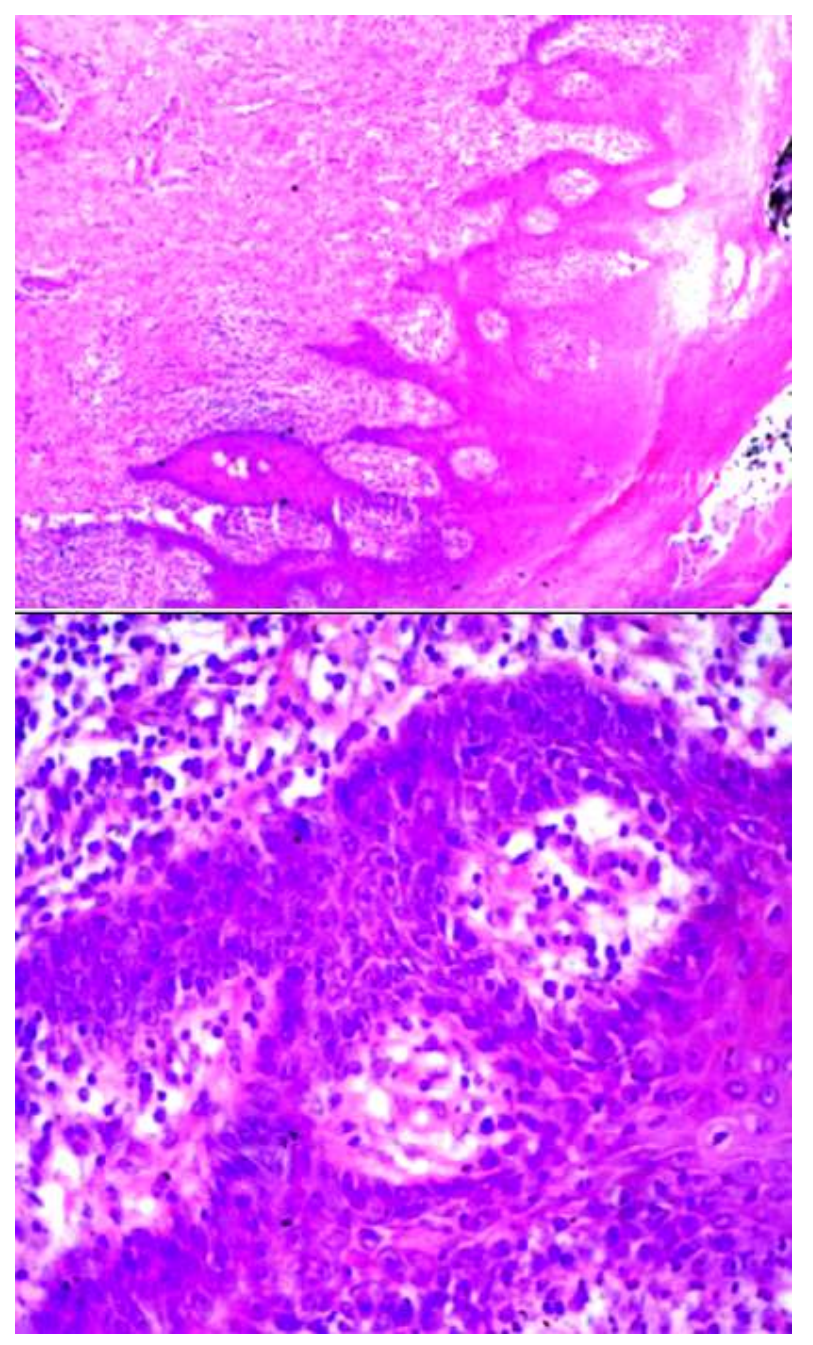

Source: Authors.

Due to the location and extension of the lesion, it was decided to treat the horse with immunomodulatory therapy. Imiquimod* was used as follows: after cleaning the perianal region with water and neutral liquid soap, 5\% imiquimod topical cream was applied to the dry region, rubbing the drug over the entire perianal region allowing it to act for 12 consecutive hours. The procedure was performed every other day, thrice a week, for four weeks. The protocol was performed four times with an interval of two weeks between protocols. In all sessions, imiquimod was administered for 16 weeks. 


\section{Results and Discussion}

Dermatology is a specialty that needs attention from equine practitioners facing other areas of equine medicine, such as gastroenterology, orthopedics, and rehabilitation. Although many skin diseases are self-limiting and not fatal, these conditions may cause major financial losses due to the aesthetic deterioration of horses, spending time, development of complications, and the eventual death of these patients (Lacerda et al., 2019).

Anamnesis, medical history, and the clinical assessment of the patient and lesion is essential in diagnosing SCC. However, confirmation is only possible through complementary examinations, emphasizing on cytological and histopathological exams (Lacerda et al., 2019). Differential diagnoses are sarcoid, pythiosis, habronemosis, exuberant granulation tissue, stephanofilariasis, papilloma, and fibropapilloma; exclusion is only possible through laboratory tests (Rabbers et al., 2014). In the present case, the presumptive diagnosis was made based on the history, clinical evaluation, and lesion characteristics. However, a definitive diagnosis was confirmed by histopathological examination of a biopsy performed on the lesion.

SCC is a malignant tumor originating from keratinocytes, which occurs more frequently in areas with hair loss and a lack of skin pigmentation, such as the eyelids, penis, or vulva (Brito et al., 2021). The occurrence of perianal SCC in horses is uncommonly reported in Brazil compared to reports of its occurrence in other locations.

Exposure to the sun is one of the leading causes of SCC development, as ultraviolet radiation can damage DNA and trigger cell mutation (Brito et al., 2021). However, this predisposing factor seems to have little influence on SCC development in our report, as the animal was exposed to sunlight only in the late afternoon, as it remained stable.

Macroscopically, they can be classified as erosive, formed by deep ulcers covered by crusts, or proliferative, which have a cauliflower appearance and bleed easily (Brito et al., 2021). In the present report, SCC was classified as erosive, as ulcers of variable depth that did not heal were observed around the anus the during clinical examination. According to the owner's report, the ulcerative lesion remained "stable" since its identification 16 months ago, corroborating with the slowgrowing and locally invasive nature of SCC (Sousa et al., 2019).

Effective and safe therapy of cancers is a clinical goal for all species. Surgery, chemotherapy, immunotherapy, and radiotherapy remain the most effective modalities for tumor treatment (Théon, 1998). The goal is to destroy tumor cells and preserve normal cells. Constraints that must be considered include the tumor type (and its particular pathological and clinical behavior), anatomic location, extent and duration of the tumor, and extent of previous interventions (Knottenbelt et al., 2015).

Although surgical resection with a wide margin is the most indicated treatment for SCC (Chacur et al., 2015), we chose to use immunotherapy in this case. The choice was mainly dictated by the location and extent of the lesion, and the failure to identify an adequate safety margin for surgical resection.

Immunotherapy represents a relatively recent anti-cancer treatment and is gaining importance in various neoplasms (melanomas, carcinomas, and sarcomas) (Théon, 1998; Mondlane et al., 2021). Immunotherapy involves the enhancement of the immune system to detect and eliminate neoplastic cells, generating a durable response and effective regression (Mondlane et al., 2021).

The chosen immunotherapeutic agent was imiquimod. Imiquimod is an immune response modifier with antiviral and anti-tumor properties and has been widely used to treat human genital warts, solar keratoses, and basal and SCCs. Imiquimod is particularly useful in areas where surgery or other treatments may be difficult, complicated, or otherwise undesirable, especially in the eyelids and ears of horses (Knottenbelt et al., 2015). In this case, the difficulty in performing total ablation of the neoplasm and the possibility of complications associated with the surgical procedure led to the choice of imiquimod.

Imiquimod, an imidazoquinoline amine, is an immune response modifier that acts as a local cell-mediated immune response stimulator and induces the production of antiviral cytokines. Imiquimod acts as an agonist of Toll-like receptor-7. It 
activates nuclear factor kappa-B, stimulating the dermal dendritic cells to express cytokines, such as tumor necrosis factor-a, interferon-a (IFN-a), and interleukins 1, 6, 8, and 12 at the site of application (Gkegkes et al., 2019). Consequently, imiquimod stimulates the immune system to release several cytokines, which are essential in the elimination of viruses and destruction of neoplastic cells (Knottenbelt et al., 2015). Furthermore, imiquimod also induces the Langerhans cells to mature and migrate to the lymph nodes, where they present antigens and induce a Th1 response. Tumor-specific T-cells are multiplied and infiltrate the affected area. At the same time, B cells start producing antibodies that subsequently increase antigen presentation (Gkegkes et al., 2019).

In the surgery for perianal SCC in a mare, intermittent abdominal pain and partial dehiscence of the surgical wound was observed. Due to the proximity of the neoplasm with the rectal ampulla, muscles, nerves, and anal sphincter, damage to these anatomical structures during a surgical procedure proved to be inevitable, justifying the reported complications (Rabelo et al., 2013). In the present report, no complications were observed with imiquimod.

When used to treat skin cancers and pre-cancerous lesions, imiquimod results in inflammation, which may destroy the lesion. The degree of inflammation varies from case to case, but most horses show moderate to severe inflammation during the treatment period (Knottenbelt et al., 2015).

A local inflammatory process was observed with the use of imiquimod after the third application. The inflammatory process was evidenced by mild edema in the perianal region and anal sphincter. Despite triggering the inflammatory process, the use of imiquimod was continued until the end of each protocol. Although human literature recommends the use of imiquimod for up to 16 consecutive weeks, the authors chose to interrupt its administration for 15 days every four weeks to reduce the inflammatory process.

Although the protocol adopted in this report was effective in perianal SCC regression, the ideal protocol for using imiquimod remains undefined. Factors such as concentration, frequency, and duration of application seem to be important in treatment. The greater the frequency of medication use, the greater the chance of cure, but higher are the adverse effects (Macedo et al., 2007).

After 16 weeks of imiquimod application, the lesion completely regressed. The horse was clinically followed for two years, and no recurrence was identified. In eight cases of SCC treated exclusively with an intralesional chemotherapeutic agent, a 25\% failure rate was obtained (Malalana et al., 2010).

Imiquimod is used relatively frequently in some cases of equine sarcoid and aural plaque (Nogueira et al., 2006); however, its use in cases of SCC is rarely described. In two reported cases (Vale et al., 2012), imiquimod failed to resolve the recurrence of SCC in one case. However, imiquimod was only used for two weeks, explaining the ineffectiveness since it is recommended to be used for 16 weeks.

The authors have used imiquimod to treat eyelid sarcoids (unpublished data) and observed an initial increase in the size of the lesion, probably due to the inflammatory process induced by imiquimod, followed by regression of the lesion. In a comparative study among 91 horses with ocular SCC, treated with or without adjuvant radiotherapy, a recurrence rate of $11.9 \%$ was observed with adjuvant radiation compared to $44.1 \%$ without radiation (Mosunic et al., 2004).

\section{Conclusion}

In conclusion, imiquimod was effective in the regression of SCC in the present report; thus, constituting a therapeutic option in cases where the location and extent of the neoplasm make the use other therapeutic modalities challenging.

\section{Manufacturers}

*3M Health Care Limited, Leicestershire, Reino Unido. 


\section{Conflict of interest statement}

The authors declare no conflict of interest. The authors alone are responsible for the content and writing of this paper.

\section{References}

Armando, F., Mecocci, S., Orlandi, V., Porcellato, I., Cappelli, K., Mechelli, L., Brachelente, C., Pepe, M., Gialletti, R., Ghelardi, A., Passeri, B. \& Razzuoli, E. (2021). Investigation of the epithelial to mesenchymal transition (EMT) process in equine papillomavirus-2 (EcPV-2)-positive penile squamous cell carcinomas. International Journal of Molecular Sciences. 22(19): 10588. https://doi.org/10.3390/ijms221910588.

Brito, G. R. \& Abreu, R. N. (2021). Carcinoma de células escamosas em equinos: relato de caso. Revista de Educação Continuada em Medicina Veterinária e Zootecnia do CRMV-SP. 19(1): e38108. https://doi.org/10.36440/recmvZ.v20i1.38108.

Chacur, M. G. M., Agostinho, B. F., Pessôa, V. M. \& Yamasaki, L. P. (2014). Clinical and laboratory evaluation of squamous cell carcinoma of the prepuce with the invasion of the spinal cord in a horse. A case report. Brazilian Journal of Veterinary Medicine. 36(1): 24-28.

Gkegkes, I. D., Iavazzo, C. \& Stamatiadis, A. P. (2019). Intra-anal use of imiquimod: what is the clinical evidence? International journal of STD \& AIDS. 30(10): 1018-1024. https://doi.org/10.1177/0956462419855828.

Halleran, J., Yau, K., Paegelow, J., Streeter, R. \& Foster, D. (2021). Mycobacterial cell wall stimulant in the treatment of squamous cell carcinoma: A case series regarding treatment in equine, bovine and caprine patients. Frontiers in Veterinary Science. 8: 635800. https://doi.org/10.3389/fvets.2021.635800.

Hibi, H., Hatama, S., Obata, A., Shibahara, T. \& Kadota, K. (2019). Laryngeal squamous cell carcinoma and papilloma associated with Equus caballus papillomavirus 2 in a horse. Journal of Veterinary Medical Science. 81(7): 1029-1033. https://doi.org/10.1292/jvms.18-0461.

Jacobsen, T. K., Neto, M. E., Veiga, Â., Figueiró, G. M. \& G. Bastiani. 2019. Uso de sulfato de vincristina no tratamento de carcinoma de células escamosas em glândula lacrimal de um equino. Acta Scientiae Veterinariae. 47(Suppl 1): 455. 10.22456/1679-9216.97259.

Knottenbelt, D. C., Patterson-Kane, J. C. \& Snalune, K. L. (2015). Clinical equine oncology. Elsevier, pp.118-200.

Lacerda, R. R., Pacheco, J. C. G., Takenaka, C. S., Torres, L. N., Matheus, M. M., Oliveira, N. F. O., Dias, D. C. R. \& Corrêa, R. R. (2019). Características clínicas, histopatológicas e imuno-histoquímicas do mastocitoma cutâneo equino: relato de caso. Revista Brasileira de Ciência Veterinária. 26(3): 64-68. 10.4322/rbcv.2019.012.

Macedo, E. M. S., Carneiro, R. C. \& Matayoshi, S. (2007). Nova modalidade no tratamento do carcinoma basocelular periocular: imiquimode. Revista Brasileira de Oftalmologia. 66(6): 411-417. https://doi.org/10.1590/S0034-72802007000600010.

Malalana F., Knottenbelt D. \& Mckane S. (2010). Mitomycin C, with or without surgery, for the treatment of ocular squamous cell carcinoma in horses. Veterinary Record. 167(10): 373-376. 10.1136/vr.c3815.

Manso-Díaz, G., Jiménez Martínez, M., García-Fernández, R. A., Herrán, R. \& Santiago, I. (2019). Mediastinal ectopic thyroid carcinoma and concurrent multinodular pulmonary fibrosis in a horse. Journal of Equine Veterinary Science. 77: 8-11. https://doi.org/10.1016/j.jevs.2019.02.016.

Mondlane, E. R., Abreu-Mendes, P., Martins, D., Cruz, R. \& Mendes, F. (2021). The role of immunotherapy in advanced renal cell carcinoma. International Brazilian Journal Urology. 47(6):1228-1242. https://doi.org/10.1590/S1677-5538.IBJU.2020.0681.

Morrison, M. L., Groover, E., Schumacher, J., Newton, J. \& Pereira, M. M. (2019). Lingual squamous cell carcinoma in two horses. Journal of Equine Veterinary Science. 79(1): 35-38. https://doi.org/10.1016/j.jevs.2019.05.022.

Mosunic, C. B., Moore P. A., Carmicheal K. P., Chandler M. J., Vidyashankar A., Zhao Y., Roberts R. E \& Dietrich U. M. (2004). Effects of treatment with and without adjuvant radiation therapy on recurrence of ocular and adnexal squamous cell carcinoma in horses: 157 cases (1985-2002). Journal of The American Veterinary Medical Association. 225(11): 1733-1738. https://doi.org/10.2460/javma.2004.225.1733.

Nogueira, S. A., Torres, S. M., Malone, E. D., Diaz, S. F., Jessen, C. \& Gilbert, S. (2006). Efficacy of imiquimod 5\% cream in the treatment of equine sarcoids: a pilot study. Veterinary Dermatology. 17(4): 259-265. https://doi.org/10.1111/j.1365-3164.2006.00526.x.

Porcellato, I., Mecocci, S., Brachelente, C., Cappelli, K., Armando, F., Tognoloni, A., Chiaradia, E., Stefanetti, V., Mechelli, L., Pepe, M., Gialletti, R., Passeri, B., Ghelardi, A. \& Razzuoli, E. (2021). PD-L1/PD-1 and CTLA-4 Expression in Equine Penile Squamous Cell Carcinomas. Animals. 11(7): 2121. https://doi.org/10.3390/ani11072121.

Rabbers, A. S., Rabelo, R. E., Vulcani, V. A. S., Sant'ana, F. J. F., Lima, C. R. O. \& Silva, L. A. F. (2014). Diagnóstico clínico, laboratorial e tratamento cirúrgico do carcinoma de células escamosas no genital de equinos machos: relatos de dois casos. Revista Brasileira de Ciência Veterinária. 21(1): 12-18. http://dx.doi.org/10.4322/rbcv.2014.020.

Rabelo, R. E., Vulcani, V. A. S., Sant'Ana, F. J. F., Vicentin, F. R., Helrigel, P. A. \& Batista, J. F. (2013). Complicações pós-cirúrgicas após a excisão de carcinoma de células escamosas na região perianal em fêmea equina. Veterinária e Zootecnia. 20(1): 47-51.

Raś, A., Otrocka-Domagała, I. \& Raś-Noryńska, M. (2020). Two different clinical forms of squamous cell carcinoma (SCC) in the perineum and vulva of two mares. BMC Veterinary Research. 16(1): 464. https://doi.org/10.1186/s12917-020-02678-9.

Scherrer, N. M., Lassaline-Utter, M. \& McKenna, B. C. (2010). Characterization and outcome following excision of masses in the nictitating membranes of horses: 50 cases (1998-2012). Journal of the American Veterinary Medical Association. 245(7): 812-815. https://doi.org/10.2460/javma.245.7.812. 
Research, Society and Development, v. 11, n. 2, e31511225710, 2022

(CC BY 4.0) | ISSN 2525-3409 | DOI: http://dx.doi.org/10.33448/rsd-v11i2.25710

Sousa, K. S., Oliveira, M. P. M., Gonçalves, T. F., Sá, I. S., Martins e Silva, K. F., Lisboa Neto, A. F., Ferreira-Silva, J. C., Lima, W. C., Machado Junior, A. A. N. \& Silva Filho, M. L. (2019). Carcinoma de células escamosas em equino: Relato de caso. Pubvet, 13(3): a292. https://doi.org/10.31533/pubvet.v13n3a292.1-6.

Stein, L., Sledge, D., Smedley, R., Kiupel, M. \& Thaiwong, T. (2019). Squamous cell carcinoma with clear cell differentiation in an equine eyelid. Journal of Veterinary Diagnostic Investigation. 31(2): 259-262. https://doi.org/10.1177/1040638718824377.

Sykora, S. \& Brandt, S. (2017). Papillomavirus infection and squamous cell carcinoma in horses. Veterinary Journal. 223(1): 48-54. https://doi.org/10.1016/j.tvj1.2017.05.007.

Théon, A. P. (1998) Intralesional and Topical Chemotherapy and Immunotherapy. Veterinary Clinics of North America: Equine Practice. 14(3): 659-671. $10.1016 / \mathrm{s} 0749-0739(17) 30191-8$

Vale, D. F., Luz, M. J., Ribeiro, S. N. , Medina, R. M. , D'Angelo, A., Silva, T. O. B. , Carvalho, C. B. \& Di Filippo, P. A. (2012) Enucleação transpalpebral para tratamento de carcinoma de células escamosas em equinos: relato de dois casos. Revista Brasileira de Medicina Eqüina. 39: 22-25. 